\title{
Tomlinsonia stichkania sp. nov., a permineralized grass from the Pliocene to (?)Pleistocene China Ranch beds in Sperry Wash, California
}

\author{
William D. Tidwell \\ E. M. V. Nambudiri
}

Follow this and additional works at: https://scholarsarchive.byu.edu/facpub

Part of the Geology Commons

\section{Original Publication Citation}

Tomlinsonia stichkania sp. nov., a permineralized grass from the Pliocene to(?) Pleistocene China Ranch beds in Sperry Wash, California. William D. Tidwell and E. M. V. Nambudiri Botanical Gazette (Chicago) (June 199), 151(2):263-274

\section{BYU ScholarsArchive Citation}

Tidwell, William D. and Nambudiri, E. M. V., "Tomlinsonia stichkania sp. nov., a permineralized grass from the Pliocene to (?)Pleistocene China Ranch beds in Sperry Wash, California" (1990). Faculty Publications. 1446.

https://scholarsarchive.byu.edu/facpub/1446

This Peer-Reviewed Article is brought to you for free and open access by BYU ScholarsArchive. It has been accepted for inclusion in Faculty Publications by an authorized administrator of BYU ScholarsArchive. For more information, please contact ellen_amatangelo@byu.edu. 


\title{
TOMLINSONIA STICHKANIA SP. NOV., A PERMINERALIZED GRASS FROM THE PLIOCENE TO (?)PLEISTOCENE CHINA RANCH BEDS IN SPERRY WASH, CALIFORNIA
}

\author{
WILLIAM D. TIDWELL AND E. M. V. NAMBUDIRI
}

Department of Botany and Range Science, Brigham Young University, Provo, Utah 84602; and Energy Research Unit, University of Regina, Saskatchewan S4S OA2, Canada

\begin{abstract}
Permineralized specimens of grasses assignable to Tomlinsonia as a new species Tomlinsonia stichkania occur in the China Ranch beds of Pliocene to possible Pleistocene age in Sperry Wash in the Alexander Hills of southeastern California. The round culm of these grasses is generally solid or occasionally hollow with collateral vascular bundles in a distinct outer and indistinct inner rings. Two-ranked leaf sheaths alternately encircle and overlap the culm. Ridges and furrows occur in the abaxial surfaces of the sheaths. The epidermis of the leaf sheaths is similar to that of the culm. The leaf lamina consists of a three-layered mesophyll. Long and short cells cannot be distinguished in the leaves, and ligules are not present. Based upon its leaf anatomy and its low $\delta^{13} \mathrm{C} /{ }^{12} \mathrm{C}$ ratios of $-24.6 \%$, this species is proposed as a $\mathrm{C}_{3}$ grass. Tomlinsonia stichkania is also important because of the rarity of permineralized grasses. It is only the second or third grass species described from specimens with this type of preservation.
\end{abstract}

\section{Introduction}

The fossil record of the Gramineae is incomplete (GOuld and SHAw 1983), and according to THOMASSON $(1980,1987 b)$, most fossil grasses described prior to 1927 were based on little factual evidence. However, paleoagrostology has come a long way since the 1920 s and recent studies of fossil grasses based on micromorphological features have increased considerably the reliability of their taxonomic determinations (THOMASSON 1980, 1984, 1987a; THOMASSON et al. 1986).

Based on the distribution of extant grasses, some investigators have postulated that grasses may have had their beginnings during the Upper Mesozoic (BROWN and SMITH 1972; BRAZIER 1973). Although grass pollen may have occurred in the Maastrichtian (KEDVES 1971), the earliest generally accepted record of fossil grasses is based on monoporate, grass-like pollen in the Paleocene of Brazil, Africa, and Australia (HARRIS 1965; PAREZRigali et al. 1974; AdEGOKE et al. 1978; Muller 1981). Plant megafossils of Gramineae do not appear in the geologic record until the Paleocene/ Eocene (LITKE 1968; CREPET and FELDMAN 1989) and grass anthoecia of Oligocene, Miocene, and Pleistocene age have been reported from various sites in the United States (THOMASSON 1987a, 1987b).

The permineralized grasses described in this report were collected on the surface in a small valley along Sperry Wash in the Alexander Hills near the southeastern edge of Death Valley National Monument, California (fig. 1). The rocks containing the grass plants were eroded from the sediments of the

Manuscript received May 1989; revised manuscript received January 1990.

Address for correspondence and reprints: WILliaM D. TIDwELL, Department of Botany and Range Science, Brigham Young University, Provo, Utah 84602. surrounding hills, which are referred to as the China Ranch beds (MASON 1948; WRIGHT 1954). They are $5,000 \mathrm{ft}(1,538 \mathrm{~m})$ or more in thickness and are unconformably overlain in some nearby areas by conglomeratic lake deposits of Pleistocene age (NOBLE and Wright 1954). The China Ranch beds have been correlated with the Funeral Formation (NOBLE 1941), and consist mostly of beds of fanglomerate and siltstone, some of which are gypsiferous. The upper beds also include marly limestones and tuffs (Wright 1954). In the Funeral Peak Quadrangle, which occurs northwest of the Alexander Hills, the Funeral Formation unconformably overlies the Greenwater volcanics, which, in turn, rests with an angular unconformity on the Furnace Creek Formation (Drewes 1963; FLECK 1970). A radiometric date of $5.4 \pm 0.2 \mathrm{Ma}$ for the Vitrophyre Member of the Greenwater volcanics provides a maximum age for the Funeral Formation (FLECK 1970), and thus, the China Ranch beds. Both DREWES (1963) and FLECK (1970) considered the Funeral Formation to be Late Pliocene to Pleistocene(?) in age. Based on pollen analysis, a Pliocene age was also inferred for part of the Funeral Formation (AXELROD and TING 1960; HUNT and MABEY 1966).

According to WRIGHT (1954), with the exception of wood fragments and a few bird tracks, the China Ranch beds were considered to be unfossiliferous. STRONG (1966) later reported permineralized tree ferns, palm axes, cycads, rootlets, and material she called petrified bog from this locality. She mentioned large logs buried in soft, clay-like ash, one of which was subsequently identified as Populus sp. (PAGE 1969), and in our recent collections, another as Betula sp. Fossil tree ferns or cycads were not collected from this locality, and based on the paleoecology of this site, it is very unlikely they were ever present. However, poorly preserved palm bases that superficially resemble cycad stems were 


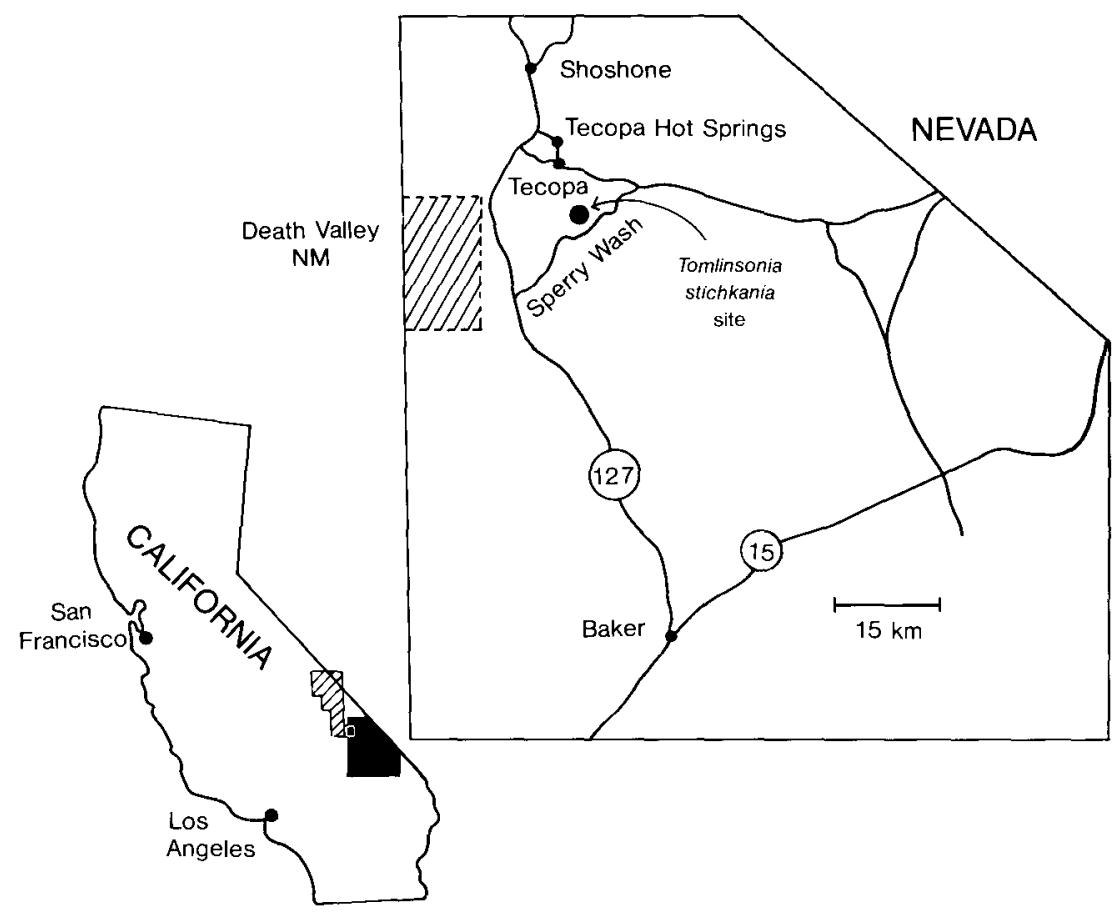

FIG. 1.-Map illustrating collection site of Tomlinsonia stichkania

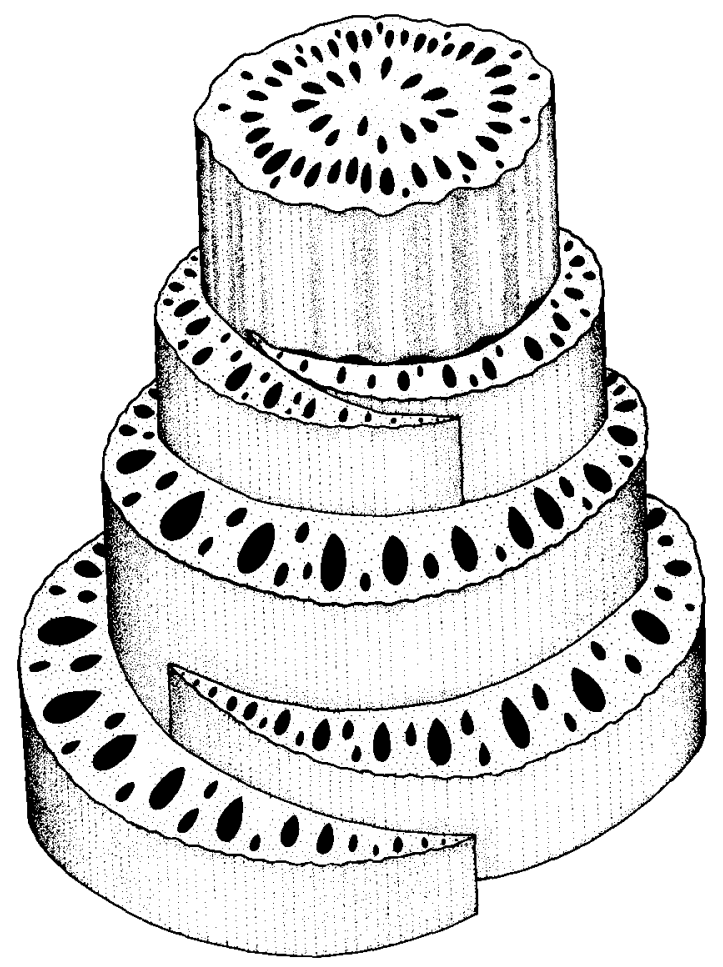

FIG. 2.-Reconstruction of a culm with ensheathing leaf bases, $\times 35$. uncovered in these beds. Other evidence of fossil palms at this locality, such as numerous roots, axes, and flowers, are also associated with the fossil grasses described in this report. Fronds of a fossil palm similar to Washingtonia sp. occur as impressions on the marly limestone beds.

\section{Material and methods}

The permineralized grass specimens referred to in this paper were first brought to our attention by Eve STICHKA and James STICHKA of Walnut Creek, California, who had discovered them in Sperry Wash during an earlier collecting trip. A subsequent trip was made to this area to locate additional material and to determine other associated fossil plant types. These other plant remains are essentially palmaceous and consist mainly of palm roots, which in some areas are so numerous as to literally form a large portion of several low hills. Thin-section slides of the specimens of fossil grass were used to study the anatomy of the plants. Some grass specimens were also dissolved in $\mathrm{HCl}$ and $\mathrm{HF}$ to remove the silicates and obtain organic material that was collected, freeze-dried, combusted to $\mathrm{CO}_{2}$, and then analyzed for its $\delta^{13} \mathrm{C} /{ }^{12} \mathrm{C}$ ratios. The result was a value of $-24.6 \%$ indicative of $\mathrm{C}_{3}$ photosynthesis.

\section{Systematics}

FAMILY.-Gramineae

GENUS. - TOMLINSONIA TIDWELL AND NAMBUDIRI SPECIES. - TOMLINSONIA STICHKANIA SP. NOV.

(FIGS. 2-23) 

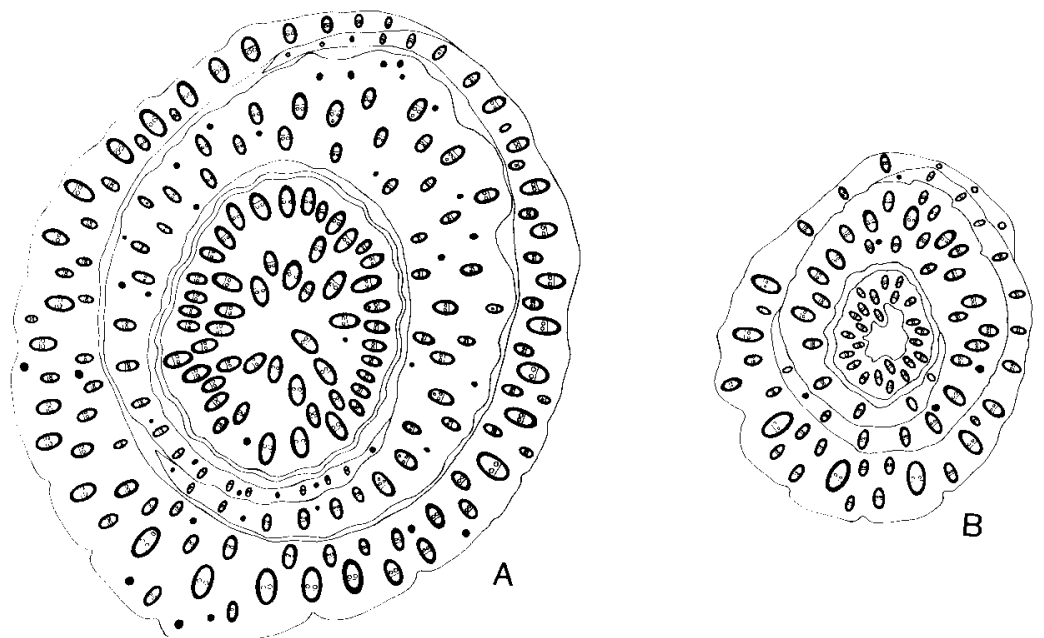

Fig. 3.-Transverse sections of culms with leaf sheaths. A, Solid culm, $\times 40$. B, Hollow culm $\times 20$

DIAGNOSIS. - Plants herbaceous; rhizome underground; culm erect, length unknown, solid or hollow, margins wavy to round; epidermis single layered, rectangular cells, collateral vascular bundles in distinct outer and indistinct inner rings; vascular bundles round to oval, bundle sheaths in three to six layers, vessels one to two, protoxylem several tracheary elements to lacunate; ground tissue parenchymatous; sheathing leaf bases, alternate, overlapping around culm, margins free, broad at middle, tapering to margins, generally rounded keel, two to three layers of vascular bundles in midrib, vascular bundles small and large, similar to culm bundles, abaxial ridges and furrows present; leaf lamina mesophyll three-layered, ligules unknown.

HOLOTYPE._Brigham Young University 3192.

PARATYPE. - Brigham Young University 3193.

LOCALITY.-Sperry Wash, Alexander Hills, California.

HORIZON. - China Ranch beds.

AGE._- Pliocene or Pleistocene (?).

ETYMOLOGY. - The specific epithet honors EVE STICHKA and James STICHKA of Walnut Creek, California, for donation of most of the fossils.

\section{Description}

The rhizome of Tomlinsonia stichkania studied (fig. 6) is $6 \mathrm{~mm}$ in diameter and consists of a poorly preserved epidermis surrounding a three-layered hypodermis, a single indistinct ring of large vascular bundles near the rhizome center, and numerous smaller bundles scattered throughout the parenchymatous ground tissue. Oblique bundles appear to connect with bundles in the culms.

The central solid to hollow culms are surrounded by alternating leaf sheaths (figs. 2, 3, 5). Sheaths are broader in their middles, tapering toward their margins (fig. 11), which although overlapping around the culm are free from one another. A distinct keel is present in one leaf sheath (fig. 16).

The culms, .5-1 $\mathrm{mm}$ in diameter, are circular or oval with a wavy outline of ridges and grooves (figs. 2, 3, 5). Squarish, four-sided, and moderately thick-walled epidermal cells form a single layer around the culm (fig. 13). They are about as long (3.5-4 $\mu \mathrm{m})$ as wide $(2.5-3 \mu \mathrm{m})$, sometimes longer. No hairs are present, or at least, none have been observed, and no definite girders or sclerenchyma occur below the epidermis (figs. 12, 13). The hypodermal region is composed of up to three layers of moderately thick-walled, squarish cells that vary from 9-24 $\mu \mathrm{m}$ long by $7-12 \mu \mathrm{m}$ wide.

Culms of these permineralized grasses have vascular bundles arranged in a more or less regular circular pattern (figs. 3, 5, 8) with an outer ring of up to 35 small bundles surrounding irregularly arranged one to three inner rings with each ring consisting of six to ten bundles. Inner bundles are often free and scattered throughout the moderately thick-walled, parenchymatous ground tissue (figs. $15,16)$. Parenchyma cells of this tissue are 15-35 

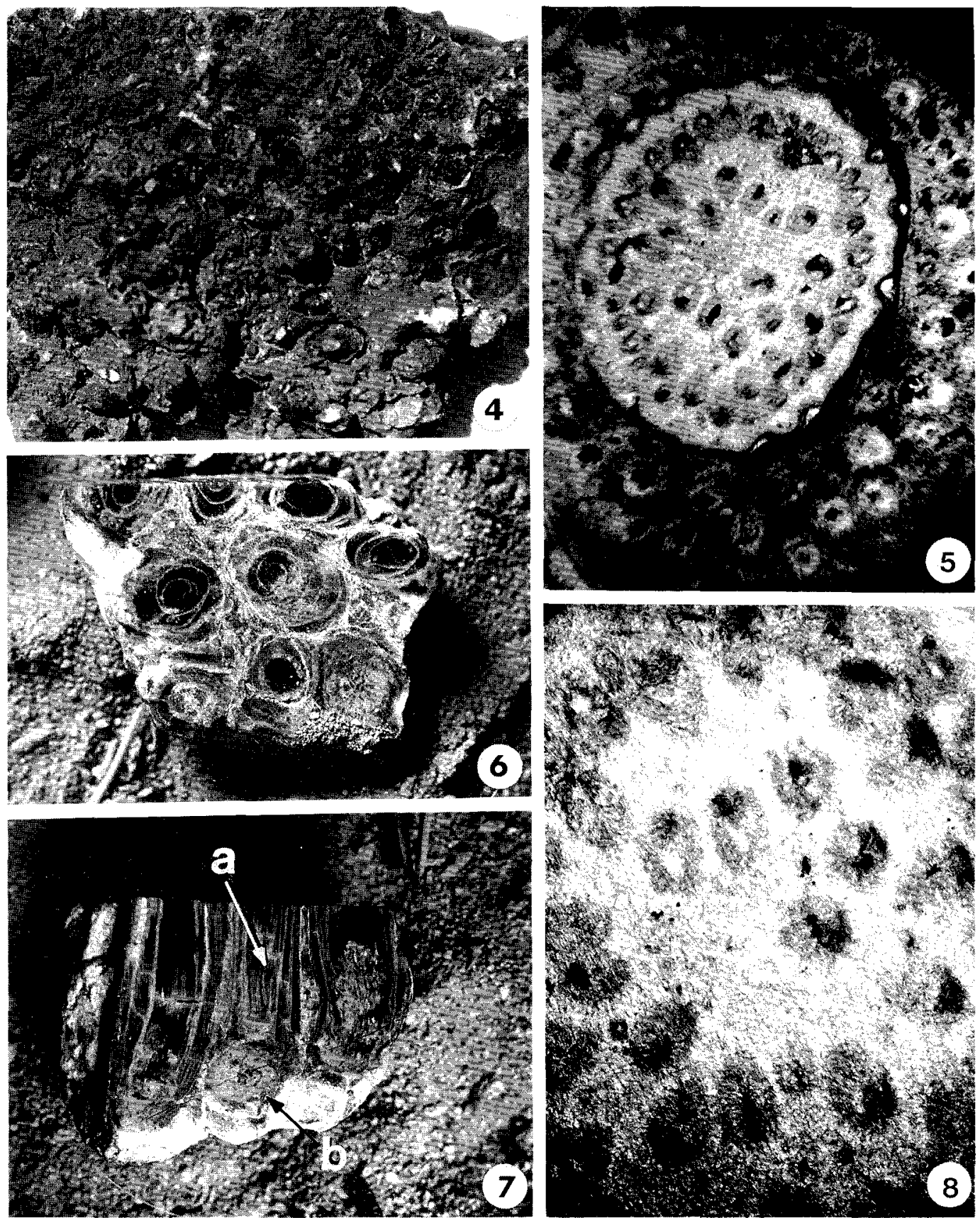

Figs. 4-8.-Illustrations of specimens and transverse section of culm. Fig. 4, Specimen before thin-sectioning. Note the numerous grass plants. Specimen no. $3193(\times 1)$. Fig. 5, Transverse section of a culm with surrounding leaf sheaths. Note the vascular bundle arrangement in the culm and the sheaths. Specimen $3192(\times 18)$. Fig. 6, Transverse section of a specimen containing several grass plants. Specimen $3192(\times 2)$. Fig. 7, Longitudinal view of the culms $(a)$ and transverse sections of the rhizomes $(b)$ of figure $6(\times 2)$. Fig. 8, Close-up of vascular bundles of the culm in figure 2; illustrating bundle distribution $(\times 25)$.

$\mu \mathrm{m}$ in size. Usually the ground tissue at the center of the culm is solid with indistinct circles of bundles embedded in its peripheral part. Only one culm has a central cavity. No air canals are present.

Outline of the vascular bundles is oval with the semicircular phloem pole occupying about one-third the height of the bundle (figs. 17, 18). The xylem poles of large bundles have one or two wide, angular to generally oval metaxylem vessels on either flank of the bundle, and a lacuna occurs in some bundles where the protoxylem appears to have disintegrated (figs. 14, 17).

Leaf sheaths with ridges and grooves on their abaxial sides are dorsiventrally flattened in a half- 

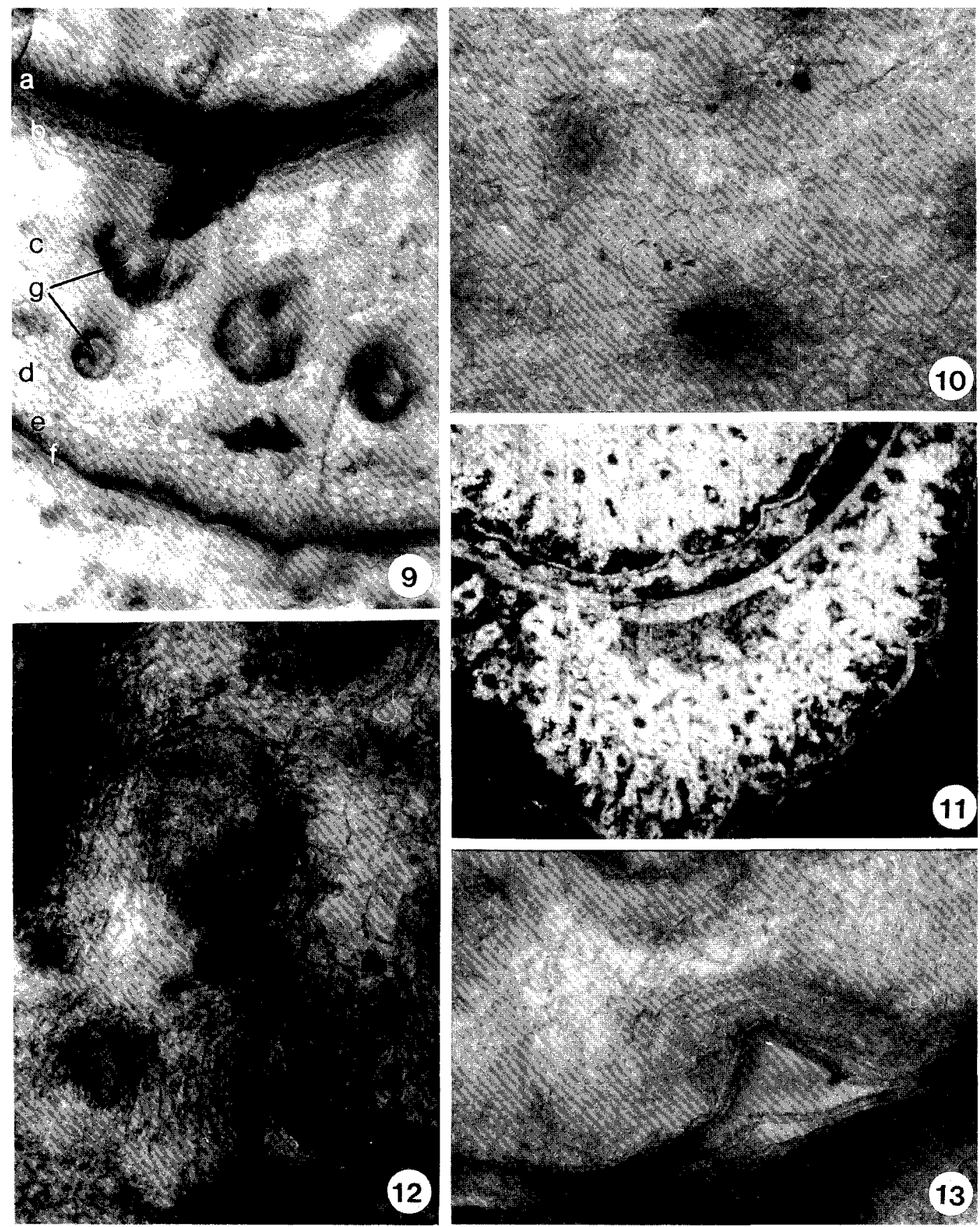

FIGs. 9-13.-Transverse sections of culms and leaves. Fig. 9, Part of a leaf lamina around culm in transverse section. Adaxial epidermis $(a)$, elongated parenchyma $(b)$, larger mesophyll cells $(c)$, smaller mesophyll parenchyma cells $(d)$, palisade-like cells $(e)$, abaxial epidermis $(f)$, and bundles $(g)$. Specimen $3192(\times 100)$. Fig. 10, Enlargement of the parenchyma cells in transverse section of the middle section of mesophyll. The darker areas are poorly preserved bundles $(\times 120)$. Fig. 11, Leaf sheath with rounded keel around culm in cross section. Note the ridges and furrows on the abaxial surface of the sheath. Specimen 3193 ( $\times$ 25). Fig. 12, Furrow of a culm in transverse section and the distribution of the small and larger vascular bundles beneath it Specimen $3192(\times 120)$. Fig. 13, Furrow and ridges of a culm in transverse section. Note the parenchyma cells of the outer ground tissue and the four-sided cells of the epidermis. Specimen $3192(\times 120)$.

moon shape around the culm (fig. 19). An abaxially projecting midrib with a round keel and complex vasculature is present (fig. 11). Around one culm, a distinct, subcircular keel is present (fig. 21). No lacunae occur in the parenchymatous ground tissue of the midrib or the mesophyll of the lamina.

The epidermal cells of the leaf and leaf sheath are uniseriate, four-sided, straight, moderately thickwalled, as long as wide or longer. They are similar to the epidermal cells of the culm. 


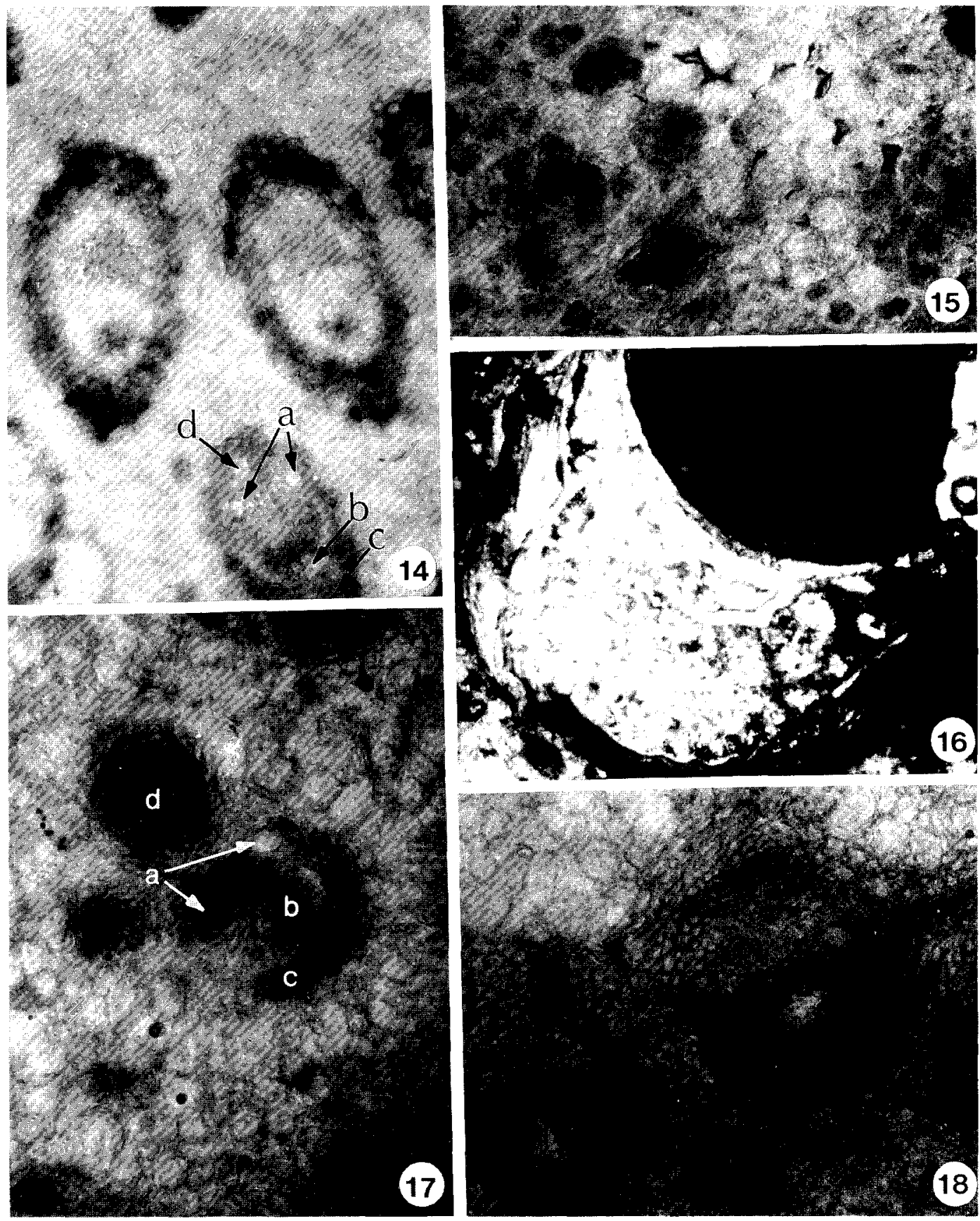

FIGS. 14-18. - Fig. 14, Vascular bundles in the middle section of the mesophyll of a leaf sheath in transverse section. Specimen $3192(\times 120)$. Fig. 15, Enlargement of the parenchyma cells of the inner ground tissue of culm in cross section. Specimen 3192 $(\times 200)$. Fig. 16, Distinct, subcircular-shaped keel of a leaf sheath in transverse section. Specimen $3193(\times 25)$. Fig. 17, Inner vascular bundle in a culm. Metaxylem vessels $(a)$, phloem $(b)$, bundle cap $(c)$, and protoxylem lacuna $(d)$. Specimen 3192 $(\times 200)$. Fig. 18, Close-up of vascular bundles of the outer ring of the culm in transverse section. Note the confluence of the bundle sheaths. Specimen $3192(\times 200)$.

The vascular bundles are embedded in parenchymatous tissue of the leaf sheaths (figs. 14, 20, 23) and the leaf lamina (fig. 9). The large primary bundles have a well-developed abaxial cap of sclerenchyma (15 $\mu \mathrm{m}$ high) but no definite girders linking them to the epidermis. The sclerotic tissue surrounding the phloem is separated from the epidermis by cells of the mesophyll. Primary bundles are ovate $(80-120 \mu \mathrm{m}$ long by $40-80 \mu \mathrm{m}$ wide) with broader sides generally abaxial. Sometimes a lysigenous cavity $(15 \mu \mathrm{m})$ is present at the position of the protoxylem, and sometimes one, but gen- 

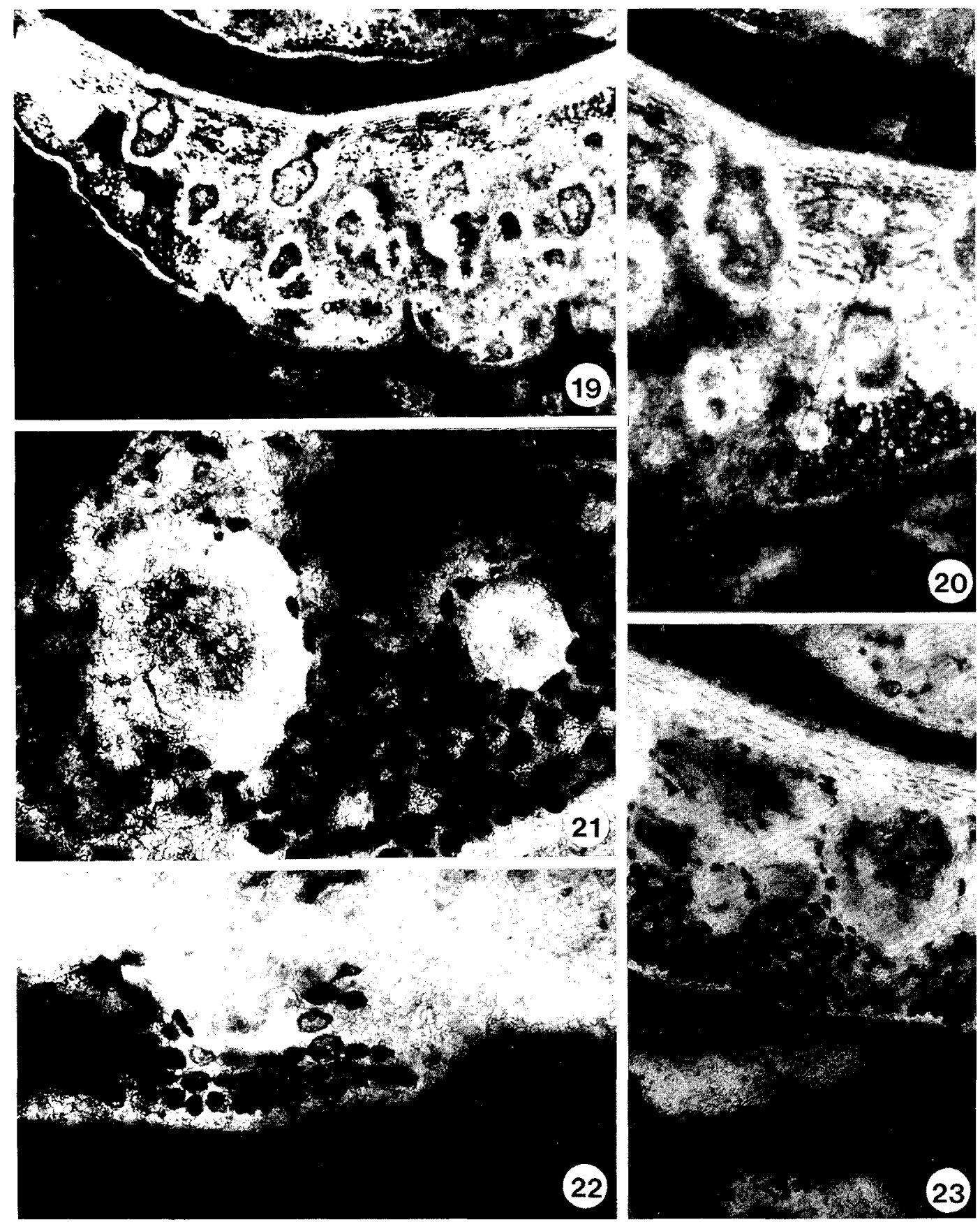

Figs. 19-23.-Fig. 19, Portion of leaf sheath showing bundle distribution and the rings and furrows on its abaxial surface. Note the smooth adaxial surface in cross section. Specimen $3193(\times 30)$. Fig. 20, Leaf sheath illustrating elongate parenchyma and the smaller cells of the mesophyll with cell contents in transverse section. Specimen 3193 ( $\times 60)$. Fig. 21, Enlargement of figure 20. Cell contents of abaxial smaller mesophyll cells and poorly preserved bundles $(\times 240)$. Fig. 22, Close-up of the elongated cells with contents in transverse section. Specimen $3193(\times 120)$. Fig. 23, Portion of leaf sheath toward the margins of figure $20(\times 20)$.

erally two, circular metaxylem vessels $(7-10 \mu \mathrm{m})$ with moderately thickened walls occur on each flank of the bundle and to the right and left of the protoxylem (fig. 14).

The bundle sheath is three to six cell layers thick. The hexagonal and elongated tangential cells of each layer are small and about the same size. Their walls are relatively thin and do not appear to be sclerotic. No bundle sheath extensions are present and no sclerenchyma occurs between the bundles.

Minor bundles are subcircular in outline and their xylem and phloem tissues are difficult to distin- 
guish from one another. Minor bundles also lack girders or any other sclerotic connecting link to the epidermis.

The mesophyll of the leaf lamina can be divided into three sections (fig. 9). An adaxial section consists of three to six layers of tangentially aligned cells that are $5 \mu \mathrm{m}$ wide by $8 \mu \mathrm{m}$ long. They parallel and are adjacent to the epidermis (figs. 22, 23). The middle portion is composed of large, moderately thickened, angular parenchyma cells (8$15 \mu \mathrm{m}$ across), which do not radiate from the bundles, and the parenchymatous abaxial section, made up of smaller cells than the others, is six to eight cell layers wide (figs. 21, 23). The cells of the outermost layer adjacent to the abaxial epidermis, although not palisades, are oriented like this tissue. They are $2.5 \mu \mathrm{m}$ wide by $3.5 \mu \mathrm{m}$ long, vertically oriented, and tightly packed. No arm cells, fusoid cells, or cavities are present.

The abaxial epidermis is similar to the adaxial epidermis. Bulliform cells, stomata, macrohairs, prickles, and minute papillae are not present on either epidermis, and short cells, silica cells, and long cells cannot be distinguished. Slight to moderately tall, rounded ribs $(100-250 \mu \mathrm{m})$ and shallow to moderately deep furrows $(20-50 \mu \mathrm{m})$ occur only on the abaxial side of the leaf.

\section{Comparison and discussion}

Vegetatively, grasses are generally distinguished by round or flattened, often hollow, jointed culms with solid nodes and alternate, two-ranked leaves (CHASE 1964). Sedges are the only plants that can be reasonably mistaken for grasses. Their culms are solid or pithy, not jointed, and commonly triangular, and the sheaths of the three-ranked leaves of sedges are generally closed (CHASE 1964; METCALFE 1971).

With the exception of several hollow culms, the false stems of Tomlinsonia stichkania are solid. Culms of corn, sugarcane, sorghum, and related grasses are also solid and pithy. Rarely in grasses is there a differentiation of the mesophyll as in $T$. stichkania. It also differs from other grasses in having two to three layers of vascular bundles in the midribs of its leaf sheaths. In the laterally flattened leaves of some species of Juncus, the bundles may occasionally appear to be two-layered, similar to T. stichkania. However, a large bundle can usually be seen at one angle, and two smaller marginal bundles occur at the opposite angle of the keel of these Juncus leaves (CUTLER 1969), thus giving the appearance of being two-layered. The bundles are embedded more or less centrally in the flatter leaves of Juncus and are more peripheral in leaves that are circular or oval in section. The shape and composition of the vascular bundles of some members of Juncus are similar to those of the fossil, but the remainder of the plant is not.
Comparisons, as drawn in table 1 , suggest that $T$. stichkania differs from the Late Miocene $T$. thomassonii Tidwell and Nambudiri (TIDWELL and NAMBUDIRI 1989) in that the former has more bundles in the outer ring of its culm. It also has ridges and furrows in the abaxial surface of its leaf sheaths and more distinct keels in its leaves. The latter features are lacking in $T$. thomassonii. In several modern grasses (i.e., Setaria and Ptychophyllum species), the leaf lamina is convolute as in $T$. stichkania. Unlike $T$. thomassonii, the internodes in culms of $T$. stichkania do not show a groove on one side. A groove is normally found on the side of the culm where a bud is developing (BOR 1960).

Leaf anatomy has been used to distinguish $\mathrm{C}_{4}$ and $\mathrm{C}_{3}$ grass species (BROWN 1975; HATTERSLEY and WATSON 1976). Many $C_{3}$ species are characterized by a chlorenchymatous mesophyll and a double-layered bundle sheath, the inner layer of which is generally of thick-walled cells. Based on its leaf anatomy and low $\delta^{13} \mathrm{C} /{ }^{12} \mathrm{C}$ ratios of $-24.6 \%$, which falls within the range of -20 to $-40 \%$ for $\mathrm{C}_{3}$ plants (LARCHER 1983), T. stichkania is proposed as a grass with a $\mathrm{C}_{3}$ photosynthetic pathway.

TIDWELl and NAMBUDiRI (1989) described $T$. thomassonii from the Upper Miocene Ricardo Formation of California. This species has Kranz anatomy and high $\delta^{13} \mathrm{C} /{ }^{12} \mathrm{C}$ ratios $(-13.7 \%$ ) that indicates a $\mathrm{C}_{4}$ photosynthetic pathway (NAMBUDIRI et al. 1978). Assigning fossil $C_{4}$ and $C_{3}$ species to the same genus (Tomlinsonia) is not unique and has precedent in modern grass floras. For example, there is no taxonomic reason for separating the $\mathrm{C}_{4}$ and $\mathrm{C}_{3}$ species of Neurachne into distinct genera (HATTERSLEY 1987), and Alloteropsis semialata from southern Africa has intraspecific photosynthetic pathway variations (ElLIS 1974; BROWN 1975; FREAN et al. 1983) with its $C_{4}$ and $C_{3}$ types being assigned to the subspecies semialata and eckloniana (GIBBS RuSSELL 1983). Other genera that contain both $\mathrm{C}_{4}$ and $\mathrm{C}_{3}$ species are Panicum and Erogrostis (ELLIS 1984; HATTERSLEY 1987).

Discovery of these permineralized grasses from the China Ranch beds and the Ricardo Formation is significant not only from the viewpoint of their micromorphological features but also because they allow speculation as to the distribution of different photosynthetic pathways in southwestern United States.

BROWN and SMITH (1972) postulated that nonKranz grasses originated during Late Mesozoic time and spread into the temperate regions of Laurasia and Gondwanaland. They assumed that panicoid grasses were the first Kranz species. It is well known that $\mathrm{C}_{4}$ species have greater efficiency for water (EDWARDS and WALKER 1983) and $\mathrm{CO}_{2}$ (GoldSWORTHY 1975) usage than do $C_{3}$ species. This capability has led to the speculation that $\mathrm{C}_{4}$ photosynthesis is an adaptation for warm, arid, subtropical 
TABLE 1

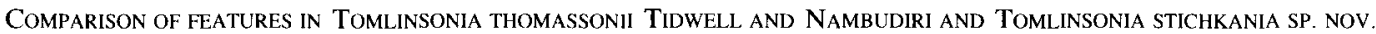

\begin{tabular}{|c|c|c|}
\hline Character & $\begin{array}{c}\text { Tomlinsonia thomassonii } \\
\text { Tidwell and Nambudiri (1989) }\end{array}$ & $\begin{array}{l}\text { Tomlinsonia stichkania } \\
\text { (this paper) }\end{array}$ \\
\hline Rhizome & $\begin{array}{l}\text { Underground, } 3 \times 3.3 \mathrm{~mm} \text {, Vascular } \\
\text { bundles in alternate rings. Primary } \\
\text { vasculature of rhizome supply branches to } \\
\text { sheathing leaf bases. Epidermis of } \\
\text { rectangular cells, hypodermis of } 6 \text { layers } \\
\text { of thick-walled cells, vascular bundles in } \\
\text { two rings }\end{array}$ & $\begin{array}{l}\text { Underground, } 6 \mathrm{~mm} \text { wide; single indistinct } \\
\text { row large bundles; numerous scattered } \\
\text { smaller bundles; parenchymatous ground } \\
\text { tissue. Epidermis indistinct, hypodermis } \\
\text { 3-layered }\end{array}$ \\
\hline \multicolumn{3}{|l|}{ Culm: } \\
\hline General & $\begin{array}{l}170-200 \mu \mathrm{m} \text { in diameter, solid, smooth or } \\
\text { wavy with ridges and grooves, vascular } \\
\text { bundles arranged in rings, one culm } \\
\text { notched }\end{array}$ & $\begin{array}{l}50-264 \mu \mathrm{m} \text { in diameter, circular to oval, } \\
\text { wavy with ridges and grooves generally } \\
\text { solid, some with central cavity }\end{array}$ \\
\hline Epidermis & Uniseriate, rectangular cells, $10 \mu \mathrm{m}$ in size & Uniseriate, rectangular thick-walled cells \\
\hline Hypodermis & $\begin{array}{l}\text { 5-layered, polygonal, moderately thick- } \\
\text { walled parenchyma. Vascular bundles } \\
\text { occasionally embedded in hypodermis }\end{array}$ & $\begin{array}{l}\text { 3-layered, moderately thick-walled squarish } \\
\text { cells }(90-145 \mu \mathrm{m} \text { long by } 72-98 \mu \mathrm{m} \\
\text { wide) }\end{array}$ \\
\hline Ground tissue $\ldots \ldots \ldots \ldots$ & $\begin{array}{l}\text { Thin-walled, round or oval parenchyma, } \\
\text { diameter } 20-30 \mu \mathrm{m} \text {, thick-walled ground } \\
\text { tissue around small vascular bundles }\end{array}$ & $\begin{array}{l}\text { Moderately thick-walled parenchyma cells, } \\
\text { diameter } 15-35 \mu \mathrm{m}\end{array}$ \\
\hline Vascular bundles .... & $\begin{array}{l}2 \text { metaxylem }(7-12 \mu \mathrm{m}) \text { and } 5 \text { protoxylem } \\
(5-7 \mu \mathrm{m}) \text { vessels, triangular to rounded; } \\
\text { phloem area }(25 \mu \mathrm{m} \text { wide) with round to } \\
\text { polygonal cells }(2-4 \mu \mathrm{m})\end{array}$ & $\begin{array}{l}\text { 1-2 wide, angular or oval metaxylem } \\
\text { vessels, protoxylem represented by } \\
\text { lacuna; phloem region semicircular }\end{array}$ \\
\hline \multicolumn{3}{|l|}{ Leaf sheath: } \\
\hline General & $\begin{array}{l}\text { Phyllotaxy alternate, abaxial surface wavy, } \\
\text { adaxial surface smooth, margins free }\end{array}$ & $\begin{array}{l}\text { Alternate phyllotaxy, abaxial surface with } \\
\text { ridges and grooves, midrib with rounded } \\
\text { keel on abaxial side }\end{array}$ \\
\hline Epidermis $\ldots \ldots \ldots \ldots \ldots$ & $\begin{array}{l}\text { Moderately thick-walled cells }(2-5 \mu \mathrm{m}) \text {. } \\
\text { Hypodermis } 5-6 \text { rows }\end{array}$ & $\begin{array}{l}\text { Uniseriate, cells rectangular, moderately } \\
\text { thick-walled }\end{array}$ \\
\hline Ground tissue & $\begin{array}{l}\text { Laterally elongated around hypodermis, } \\
\text { otherwise rounded or oval parenchyma }\end{array}$ & Parenchymatous, nonlacunar \\
\hline Vascular bundles & $\begin{array}{l}\text { Outer bundles surrounded by up to } 8 \text { rows } \\
\text { of thick-walled cells, inner vascular } \\
\text { bundles with thinner sheaths. } 2 \\
\text { metaxylem and up to } 10 \text { protoxylem } \\
\text { vessels. Phloem present. Small and large } \\
\text { bundles alternating }\end{array}$ & Similar to those in leaf lamina \\
\hline \multicolumn{3}{|l|}{ Leaf lamina: } \\
\hline General & $\begin{array}{l}\text { Dorsiventral, mesophyll parenchymatous, } \\
\text { midrib lacking }\end{array}$ & $\begin{array}{l}\text { Shallow ridges and grooves on abaxial } \\
\text { epidermis, adaxial epidermis smooth. } \\
\text { Mesophyll differentiated into outer, } \\
\text { middle, and inner }\end{array}$ \\
\hline Epidermis & $\begin{array}{l}\text { Uniseriate with a hypodermis of up to } 3 \\
\text { layers of parenchyma cells }\end{array}$ & $\begin{array}{l}\text { Uniseriate, cells rectangular and moderately } \\
\text { thick-walled }\end{array}$ \\
\hline Mesophyll tissue . . . . . . . & $\begin{array}{l}\text { Round, oval or laterally elongated } \\
\text { parenchyma cells, } 3-5 \text { cells between } \\
\text { bundles }\end{array}$ & $\begin{array}{l}\text { Mesophyll cells on the adaxial epidermis } \\
\text { tangentially elongated. Mesophyll in the } \\
\text { middle part of the leaf of moderately } \\
\text { thick-walled angular parenchyma cells. } \\
\text { Cells similar to palisade tissue along the } \\
\text { abaxial side and small parenchyma } \\
\text { subtending these cells }\end{array}$ \\
\hline Vascular bundles & Major veins alternate with minor bundles & $\begin{array}{l}\text { Major bundles with protoxylem lacuna. } \\
\text { Minor bundles lack girder cells or any } \\
\text { connection with the epidermis }\end{array}$ \\
\hline Root & $\begin{array}{l}\text { Diameter } 790 \mu \mathrm{m} \text {, cortex divided into a } \\
\text { hypodermal zone, a middle aerenchyma } \\
\text { tissue and up to } 3 \text { layers of polygonal } \\
\text { parenchyma forming inner cortex. Stele, } \\
156 \mu \mathrm{m} \text {, with uniseriate endodermis and } \\
\text { pericycle. Metaxylem vessels } 6 \text {, round to } \\
\text { oval. Protoxylem and phloem } \\
\text { indistinguishable }\end{array}$ & Unknown \\
\hline $\begin{array}{l}\text { Photosynthetic pathways } \\
\qquad\left(\delta^{13} \mathrm{C} /{ }^{12} \mathrm{C} \text { ratios }\right) \ldots \ldots\end{array}$ & $-13.7\left(C_{4}\right)$ & $-24.6\left(\mathrm{C}_{3}\right)$ \\
\hline
\end{tabular}


to tropical areas (SMITH 1976). According to MoORE (1983), $\mathrm{C}_{4}$ and CAM plants are better suited to increasing aridity and higher temperatures due to their water efficiency. In low temperate regions, $\mathrm{C}_{4}$ photosynthesis is considerably retarded. GoLDSWORTHY (1975) proposed that $\mathrm{C}_{4}$ photosynthesis evolved when $\mathrm{CO}_{2}$ and $\mathrm{O}_{2}$ atmospheric levels reached present-day ratios. The theory of an oxygen-rich and a $\mathrm{CO}_{2}$-depleted atmosphere through geological time suggests that oxygen levels were relatively low during the Late Paleozoic and Early Mesozoic (TAPPAN 1968). Consequently, $\mathrm{C}_{3}$ photosynthesis was the first to evolve because in the low oxygen atmosphere the most efficient method of photosynthesis was the conversion of ribulose diphosphate to 3-phosphoglyceric acid in the presence of the enzyme RuDP carboxylase (SMITH 1976). However, in an oxygen-rich atmosphere phosphoglycolates are produced from RuDP and efficient use of $\mathrm{CO}_{2}$ is considerably retarded. It is conceivable, therefore, that $\mathrm{C}_{4}$ photosynthesis evolved when the atmospheric oxygen levels reached the present-day concentration. Oxygen levels fluctuated during Jurassic and Cretaceous periods and an atmosphere with higher oxygen level was proposed for the mid-Cretaceous, declining toward the K-T boundary (TAPPAN 1968; Odum 1971). Atmospheric enrichment of $\mathrm{CO}_{2}$ during the Late Cretaceous $(70 \mathrm{Ma})$ could easily have been achieved through widespread volcanism (CLOUD and GIBOR 1970; MOORE 1983) throughout North America. It is possible, therefore, that $\mathrm{C}_{4}$ photosynthesis originated prior to this increase in atmospheric $\mathrm{CO}_{2}$. However, all reported occurrences of $\mathrm{C}_{4}$ fossil grasses are in Miocene and younger strata (NAMBUDIRI et al. 1978; THOMASSON et al. 1986; TIDWELL and NAMBUDIRI 1989). Therefore, evidence for the actual age for the beginning of $\mathrm{C}_{4}$ photosynthesis, particularly in grasses, must await discovery of earlier fossils.

The appearance of grass pollen in the Green River Formation of Utah and Colorado in association with members of the Leguminosae, Sapindaceae, and Anacardiaceae implies the existence of a savanna woodland vegetation in the area during the Eocene (MACGinitie 1969). WOLFE (1985, pp. 357-375), however, considered the Green River plant assemblages to be more similar to a megathermal or very warm mesothermal semideciduous forest. $\mathrm{Al}$ though plant communities of varying composition and physiognomy constitute savannas, their vegetation typically includes a continuous grass cover with trees and shrubs (COLE 1986). The possible existence of Eocene savannas in the western United States is also supported by data on faunal adaptations to savanna living conditions (WEBB 1977, p. 359). According to RETALLACK (1988), however, fossil soils suggest that despite the associated mal- adapted faunas, the origin of the grasslands was most likely during the Oligocene. There is evidence from faunal remains (BLACK and DAwSON 1966) that the Rocky Mountain savannas extended into California where seasonal aridity induced rapid growth and expansion of the Madro-Tertiary Geoflora (AXELROD 1950; ADDICOTT 1970).

Until recently, there were no reports of an open prairie in the Miocene grasslands in the United States (MACGinitie 1962; AXELrod 1985; WOLFE 1985, pp. 357-375). However, a diverse fauna of Miocene ungulates with adaptations for coarse fodder intake suggests an extensive grassy vegetation. This coincided with a time span of extensive grass fossils in central North America (EliAs 1942; THOMASSON 1980, 1984, 1987a) and California (TIDWELL and NAMBUDIRI 1989). It is known that a major part of the arid to semiarid southwestern United States was covered by a steppe by Pliocene time (WEBB 1977).

Sediments associated with the plants of $T$. stichkania may provide a clue to the environment in which they grew. The fanglomerates in the China Ranch beds were originally formed as alluvial fans (LAWSON 1925; BULL 1972) that had accumulated during the Late Pliocene. They vary in texture from coarse boulders and megabreccias to pebbles lacking sorting and stratification (NOBLE and WRIGHT 1954). According to BULL (1972) and ETHRIDGE (1985), alluvial fans are conspicuous features in semiarid and arid regions where streams dwindle rapidly in size after they leave mountain canyons and immediately drop their larger material, whereas in humid regions, fans normally consist of finer sediments and more gently sloping surfaces. Alluvial fans readily develop in regions of steep slopes rather than where slopes are gentle. The marly limestones in which some of the fossils occur are siliceous and suggest the presence of a small, possibly ephemeral, lake or oasis affiliated with some volcanism (PETTIJOHN 1957). The grasses probably grew around this lake, associated with numerous Washingtonia-like palms, poplars, and birch trees, in a valley that was surrounded by relatively steepsloped mountain ranges. This postulated streamside or lakeside environment is similar to the present native environment of Washingtonia palms, which is riparian (SMITH 1958). They grow natively in desert canyons and around oases in southern California, adjacent Arizona, and Baja California (SMITH 1958).

AXELROD and TING (1960) projected a 25 -inch $(63.5 \mathrm{~cm})$ rainfall with both summer and winter storms for the Nova flora in the Funeral Formation (HUNT and MABEY 1966) from the west flank of the nearby Central Panamint Range. Based on the above inferences, this rainfall amount seems high. With regards to the postulated climatic conditions 
for this region by AXELROD and TING (1960), it is interesting that FENNEMAN (1931, pp. 348-349), in comparing Minnesota with Nevada and the Great Basin, noted that if Minnesota had an arid climate like Nevada, it would have desert basins and lakes with only interior drainage. Conversely, if Nevada had the rainfall of Minnesota (20-32 inches or 50.9 $81.4 \mathrm{~cm}$ ), all the basins would fill and eventually overflow to the sea. There is no evidence of the latter happening during the Late Pliocene in the Great Basin.

Apart from the speculative arrival of grasses during Upper Mesozoic times (Brown and SMITH 1972), the likely route of $C_{4}$ grass species into western North America is migration of old world species through Beringia (MCKENNA 1975; Russel and ZHAI 1987). Another possibility is through waif dispersal between North and South America before the Panamanian land bridge was in place ca. $3 \mathrm{Ma}$ (MARSHALL 1988).

\section{Acknowledgments}

The authors extend their appreciation to EvE STICHKA and JAMES STICHKA for donating most of the specimens; to Professor Bruce SMITH and NAOMI HEBBERT of Brigham Young University for aid with the photosynthesis analysis; to Doug Moore of Glendora, California, BILL ROBERTSON of Fontana, California, THOMAS BLACK of Brigham Young University, and LEITH TIDwELl of Provo, Utah for assistance with fieldwork and collecting; to Professors J. Keith Rigby, J. R. Thomasson, and S. R. AsH for reviewing the manuscript; and a special thanks to BRIAN BROWN of China Ranch for allowing us access to the ranch property.

\section{LITERATURE CITED}

Addicotr, W. 1970. Tertiary palaeoclimatic trends in the San Joaquin Valley, California. U.S. Geol. Surv. Prof. Paper 644:1-19.

Adegoke, O. S., R. E. Jan Du Chene, and A. E. Agumanu 1978. Palynology and age of the Kerri-Kerrir Formation, Nigeria. Rev. Esp. Micropaleont. 10:267-283.

AXELROD, D. I. 1950. Evolution of desert vegetation in western North America. Carnegie Inst. Washington Publ. 590:215306.

-1985. Rise of the grassland biome, central North America. Bot. Rev. 51:163-201

AXELRoD, D. I., and W. A. Ting. 1960. Late Pliocene floras east of the Sierra Nevada. Univ. Calif. Publ. Geol. Sci. 39:1118 .

Black, C. C., and M. R. Dawson. 1966. A preview of Late Eocene mammalian faunas from North America. Am. J. Sci 264:321-349.

BOR, N. L. 1960. The grasses of Burma, India and Pakistan International Series of Monographs on Pure and Applied Biology, Division of Botany, vol. 1. Pergamon, New York.

Brazier, M. D. 1973. Grass roots at the base of the Neogene. Nature 243:342.

Brown, W. V. 1975. Variation in anatomy, associations and origins of Kranz tissue. Am. J. Bot. 62:395-402.

Brown, W. V., and B. N. SMITH. 1972. Grass evolution, the Kranz syndrome, $\delta^{13} \mathrm{C} /{ }^{12} \mathrm{C}$ ratios, and continental drift. Nature 239:345-346

BuLL, W. B. 1972. Recognition of alluvial fan deposits in the stratigraphic record. Pages 63-83 in J. K. RigBY and W. K. HAMBLIN, eds. Recognition of ancient sedimentary environments. Special Papers, no. 16. Society of Economic Paleontologists and Mineralogists, Tulsa, Okla.

Chase, A. 1964. First book of grasses. Smithsonian Institution Press, Washington, D.C.

Cloud, P., and A. Gibor. 1970. The oxygen cycle. Sci. Am. 233:110-123.

CoLE, M. M. 1986. The savannas, biogeography and geobotany. Academic Press, London.

Crepet, W. L., and G. D. Feldman. 1989. Paleocene/Eocene grasses from the southeastern USA. Am. J. Bot. Suppl. 76(6): 161 .

CUTLER, D. F. 1969. Anatomy of the monocotyledons. IV Juncales. Clarendon, Oxford.

DrewEs, H. 1963. Geology of the Funeral Peak Quadrangle, California on the east flank of Death Valley. U.S. Geol. Surv. Prof. Paper 413: $1-78$.
Edwards, G., and D. WalKer. 1983. $\mathrm{C}_{3}, \mathrm{C}_{4}$ mechanisms and cellular and environmental regulation, photosynthesis. University of California Press, Berkeley and Los Angeles.

Elias, M. K. 1942. Tertiary prairie grasses and other herbs from the High Plains. Geol. Soc. Am. Spec. Paper 41:1176.

Ellis, R. P. 1974. The significance of the occurrence of both Kranz and non-Kranz leaf anatomy in the grass species $\mathrm{Al}$ loteropsis semialata. S. Afr. J. Sci. 70:169-173.

1984. Eragrostis walteri - a first record of non-Kranz leaf anatomy in the sub-family Chloridoideae (Poaceae). S. Afr. J. Bot. 3:80-386.

ETHRidGe, F. G. 1985. Modern alluvial fans and fan deltas. Pages 101-126 in R. M. FlorEs et al., eds. Recognition of fluvial depositional systems and their resource potential. Short Course no. 19. Society of Economic Paleontologists and Mineralogists, Tulsa, Okla.

FENNEMAN, N. M. 1931. Physiography of western United States. McGraw-Hill, New York.

FleCK, R. J. 1970. Age and tectonic significance of volcanic rocks, Death Valley area, California. Geol. Soc. Am. Bull. 81:2807-2816.

Frean, M. L., D. R. Barrett, D. Ariovich, M. Wolfson, and C. F. Cresswell. 1983. Intraspecific variability in Alloter opsis semialata (R. Br.) Hitchc. Bothalia 14:901-913.

GibBs Russell, G. E. 1983. The taxonomic position of $\mathrm{C}_{3}$ and $\mathrm{C}_{4}$ Alloteropsis semialata (Poaceae) in southern Africa. Bothalia 14:205-213

Goldsworthy, A. 1975. Photorespiration in relation to crop yield. Pages 329-348 in U. S. GUPTA, ed. Physiological aspects of dryland farming. Allanheld, Osmun \& Co., Montclair, N.J.

Gould, F. W., and R. B. ShaW. 1983. Grass systematics. Texas A\&M University Press, College Station.

HarrIS, W. K., 1965. Tertiary microfloras from Brisbane, Queensland. Geol. Surv. Queensland, Report no. 10:1-7.

Hattersley, P. W. 1987. Variations in photosynthetic pathway. Pages 49-64 in T. R. Soderstrom, K. W. Hiln, C. S. CAMPBell, and M. E. Barkworth, eds. Grass systematics and evolution. Smithsonian Institution Press, Washington, D.C

Hattersley, P. W., and L. Watson. 1976. C 4 grasses: an anatomical criterion for distinguishing between NADP-malic enzyme species and PCK or NAD-malic enzyme species. Austr. J. Bot. 24:297-308.

HunT, C. B., and D. R. MABEY. 1966. General geology of 
Death Valley, California-stratigraphy and structure. U.S. Geol. Surv. Prof. Paper 494-A:Al-A165.

KEDVES, M. 1971. Presence de types sporomorphes importants dans les sediments prequaternairees Egyptiens. Acta Bot. Acad. Sci. Hung. 17:371-378.

LARChER, W. 1983. Physiological plant ecology. Springer-Verlag, New York and Tokyo.

LAWSON, A. C. 1925. The petrographic designation of alluvial fan formation. Univ. Calif. Pub. Geol. Sci. 7:325-334

LITKE, R. 1968. Uber den Nachweis tertiarer Gramineen. Sond. Monat. Deutsch. Akad. Wiss. Berlin 18:462-471.

MacGinitiE, H. D. 1962. The Kilgore flora: a Late Miocene flora from northern Nebraska. Univ. Calif. Publ. Geol. Sci. 35:66-158.

1969. The Eocene Green River flora of northwestern Colorado and northeastern Utah. Univ. Calif. Publ. Geol. Sci. 83: 1-203.

McKenna, M. C. 1975. Fossil mammals and Early Eocene North Atlantic land continuity. Ann. Miss. Bot. Gard. 62:335353.

MARShall, L. G. 1988. Land mammals and the great American interchange. Am. Sci. 76:380-388.

MASON, J. F. 1948. Geology of the Tecopa area, southeastern California. Geol. Soc. Am. Bull. 59:333-352.

Metcalfe, C. R. 1971. Anatomy of the monocotyledons. V. Cyperaceae. Clarendon, Oxford.

MOORE, P. D. 1983. Plants and the palaeoatmosphere. J. Geol. Soc. London 140:13-25.

MULLER J. 1981. Fossil pollen records of extant angiosperms. Bot. Rev. 47:1-142.

NAmbudiri, E. M. V., W. D. Tidwell, B. N. Smith, and N. P. HebBert. 1978. A $C_{4}$ plant from the Pliocene. Nature 276:816-817.

Noble, L. F. 1941. Structural features of the Virgin Spring area, Death Valley, California. Geol. Soc. Am. Bull. 52:9411000 .

Noble, L. F., and L. A. Wright. 1954. Geology of the central and southern Death Valley region, California. Pages 143160 in R. H. JAHNS, ed. Geology of southern California. Calif. Div. Mines Bull. 170. Division of Mines, San Francisco.

Odum, E. P. 1971. Fundamentals of ecology. 3d ed. W. A. Saunders, Philadelphia.

PAGE, V. M. 1969. Gems and minerals handbook: how to identify fossil wood. VI. Identification plates. Gems and Min. 385:33-36.

Parez-Rigali, M. D. S., N. Mfsugui, and A. D. S. Santos. 1974. Palynologia dos sedimentos meso-cenozoicas do Brasil (I). Bol. Tecn. Petrobas., Rio de Janeiro 7:177-191.
Pettuohn, F. J. 1957. Sedimentary rocks. 2d ed. Harper \& Brothers, New York.

RETALlaCK, G. J. 1988. Down-to-earth approaches to vertebrate paleontology. Palaios 3:335-344.

Russel, D. E., and R. J. ZhAI. 1987. The Paleogene of Asia: mammals and stratigraphy. Me. Mus. Nat. Hist. Natur., Sci. de la Terre 52:1-488.

SMITH, B. N. 1976. Evolution of $\mathrm{C}_{4}$ photosynthesis in response to changes in carbon and oxygen concentrations in the atmosphere through time. BioSystems 8:24-32.

SMith, D. 1958. The California habitat of Washingtonia filifera. Principes 2:41-51.

STRONG, M. F. 1966. Desert gem trails--a field guide to the gem and mineral localities of the Mojave and Colorado Deserts, and adjacent areas of Nevada and Arizona. Gembooks, Mentone, Calif.

TAPPAN, H. 1968. Primary production, isotopes, extinctions and the atmosphere. Palaeogeogr., Palaeoclimatol., Palaeoecol. 4:187-210

Thomasson, J. R. 1980. Paleoagrostology: a historical view. Iowa St. J. Res. 54:301-317.

1984. Miocene grass (Gramineae: Arundinoideae) leaves showing external micromorphological and internal anatomical features. BOT. GAZ. 145:204-209.

$1987 a$. Late Miocene plants from northeastern $\mathrm{Ne}$ braska. J. Paleo. 61:1065-1079.

1987b. Fossil grasses: $1820-1986$ and beyond. Pages 159-167 in T. R. Soderstrom, K. W. Hiln, C. S. CAMPBELL, and M. E. BARKWORTH, ed. Grass systematics and evolution. Smithsonian Institution Press, Washington, D.C.

Thomasson, J. R., M. E. Nelson, and R. J. Zakrezewski. 1986. A fossil grass (Gramineae: Chloridoideae) from the Miocene with Kranz anatomy. Science 233:876-878.

Tidwell, W. D., and E. M. V. NAmbudiri. 1989. Tomlinsonia thomassonii, gen. et sp. nov., a new permineralized grass from the Upper Miocene Ricardo Formation, California. Rev. Palaeobot. Palynol. 60:165-177.

WEBB, D. S. 1977. A history of savanna vertebrates in the New World. 1. North America. Ann. Rev. Ecol. Syst. 8:355 380 .

Wolfe, J. A. 1985. Distribution of major vegetational types during the Tertiary: the carbon cycle and atmospheric $\mathrm{CO}_{2}$ : natural variation Archean to present. Geophysical Monograph no. 32. American Geophysical Union, Washington, D.C.

Wright, L. A. 1954. Geology of the Alexander Hills area, Inyo and San Bernardino Counties. Map sheet 17 in R. H. JAHNS, ed. Geology of southern California. Calif. Div. Mines Bull. 170. Division of Mines, San Francisco. 